\title{
A TRIBUTE
}

\section{Blair Dillard Erb, MD: 1930-2021}

"There are strange things done in the midnight sun by the men who moil for gold." When I hear those words, I see Blair Erb standing at the presidential podium at a Wilderness Medical Society (WMS) meeting with a copy of Robert Service's poetry in his hand. Blair was the epitome of a Renaissance man who always brought a sense of decorum and class to any function. Along with being an astute clinical cardiologist, he was renowned for his storytelling and great love of the outdoors.

Blair was born in the hills of Virginia but moved to the flatlands of Memphis, Tennessee, where he was raised along with his older brother. He learned to love the outdoors at an early age and achieved the rank of Eagle Scout, no mean feat during the 1940s. As another sign of an outstanding work ethic and intellect, Blair completed undergraduate and medical school in 5 years at The University of Tennessee. The Blue Ridge Mountains must have been in his blood, however, for he developed a great love for the "high places," and as an Air Force flight surgeon stationed in Colorado, he was smitten by the mountains.

He was also smitten around this time by Sally Smith, to whom he was happily married for 45 years. Sally and Blair had 3 children, who accompanied them on many camping, climbing, and other adventures. I had the pleasure of making Sally's acquaintance on many occasions, and she was the perfect match for Blair.

Blair's accomplishments in the field of medicine over 30-plus years were legend. His expertise in exercise physiology, cardiology, and cardiac rehabilitation made him an international authority and led him to the WMS, where he became a long-time board member and president. He never lost his love for the mountains, and he combined his medical expertise with high altitude and mountaineering.

I remember Blair not so much for his medical knowledge but for his love of the liberal arts. He could expatiate on the history of the national parks, the Civil War, types of aircraft, the poetry of Longfellow, or the essays of Emerson. He could tell stories that would make you laugh out loud or cry inside. Most importantly, he did everything with Class, with a capital "C." I learned a

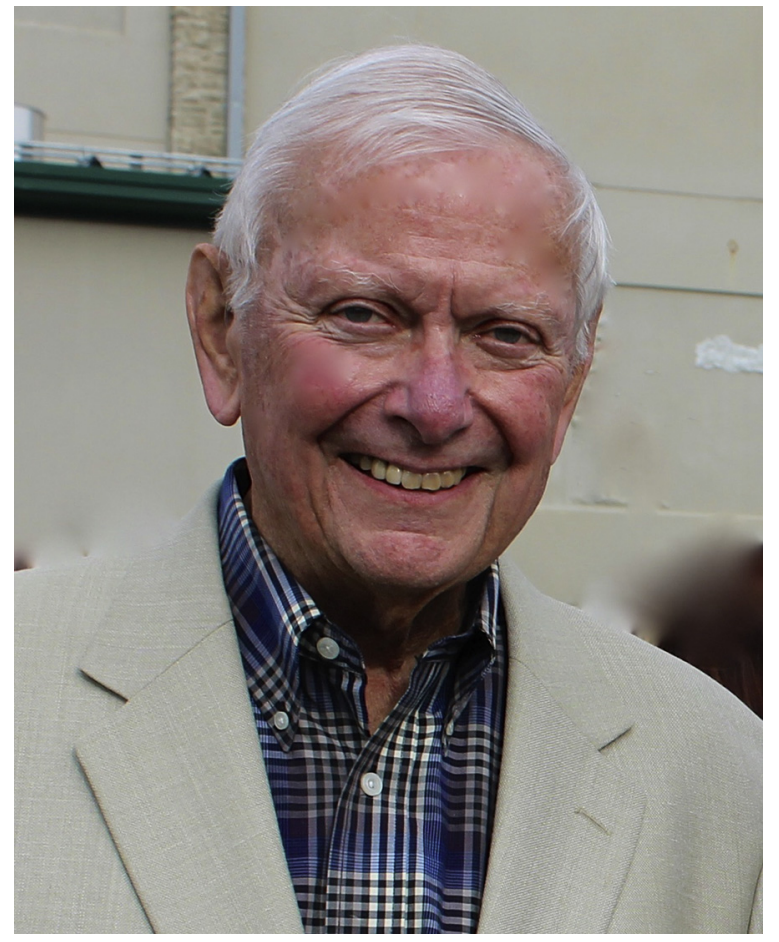

Blair Dillard Erb, MD, in 2015. Photo courtesy of Mary Lou Layton.

great deal from Blair, and I can see why his patients loved him. He showed me not just how to do things right, but how to do the right things in the correct manner. Having dinner with Blair and Sally was always the high point of a meeting, and I will sorely miss him.

Edward J. (Mel) Otten, MD

Gracious and humble, Blair was the consummate Southern gentleman/physician. I will never forget his assistance in obtaining independent accreditation to sponsor our own continuing medical education events. We partnered with the University of California San Diego for our first couple of WMS meetings, and they served as our sponsor for continuing medical education accreditation. The WMS was growing, and even picking up some 
international members, so we knew it was time to pursue our own accreditation status. The paperwork was mindboggling and a formidable hurdle for the founders, who were already juggling busy work schedules. Blair had just gotten involved with the WMS, and I discussed with him the challenge of working through the accreditation process. Without hesitation, he jumped right in to assist, saying, "I know the hell out of these organizations. Let me help." Indeed he did, and we got our accreditation. That was Blair-a wonderful combination of experience, enthusiasm, and willingness to roll up his sleeves and get the job done.

Edward Geehr, MD

Though I never got to work with Blair during his time on the WMS board or during his presidency, I became acquainted with him as an elegant presence at society functions. He had the voice and embodiment of a stately uncle or grandfather; when Blair showed up, everyone stood up straight and checked their diction and politeness. WMS meetings are informal (and some have been known to take that to the extreme), but even the most disheveled among us took care to comb our hair and tuck in our shirttails when Dr. Erb was nearby. Blair was a traditional Southern gentleman; the first female WMS president threw him a curveball when he wanted to continue the "green jacket" tradition. We chuckled over how it was going to work for me and future presidents who didn't fit into, for example, a $42 \mathrm{~L}$ suit coat. I found a suitable lady's jacket and he mailed me the custom-made WMS buttons to sew on to the jacket. (It was ugly, but it made him smile to see all of us in our green jackets at the next meeting.) His grace and elegance will be missed.

Luanne Freer, MD

There will always be a critical moment in the development of a new organization as it transitions from its founders into a mature program. Blair Erb, MD, will be recalled by the many who knew him, both by the WMS founders and those members who followed, as a true Southern gentleman. He had the ability to calmly lead this fledgling organization into its maturity through, at times, turbulent waters.

Under his guidance, the WMS expanded its scope of membership, integrated multiple competing wilderness medicine programs into cooperation, oversaw attempts at standardization of curricula, and championed the editing of comprehensive practice guidelines.

He established the evening annual dinner and elevated its stature into the grace of a semiformal affair, resplendent with an increasing number of awards honoring members' contributions; initiated green jackets for past presidents; established the first international wilderness medicine conference as one of our annual meetings every

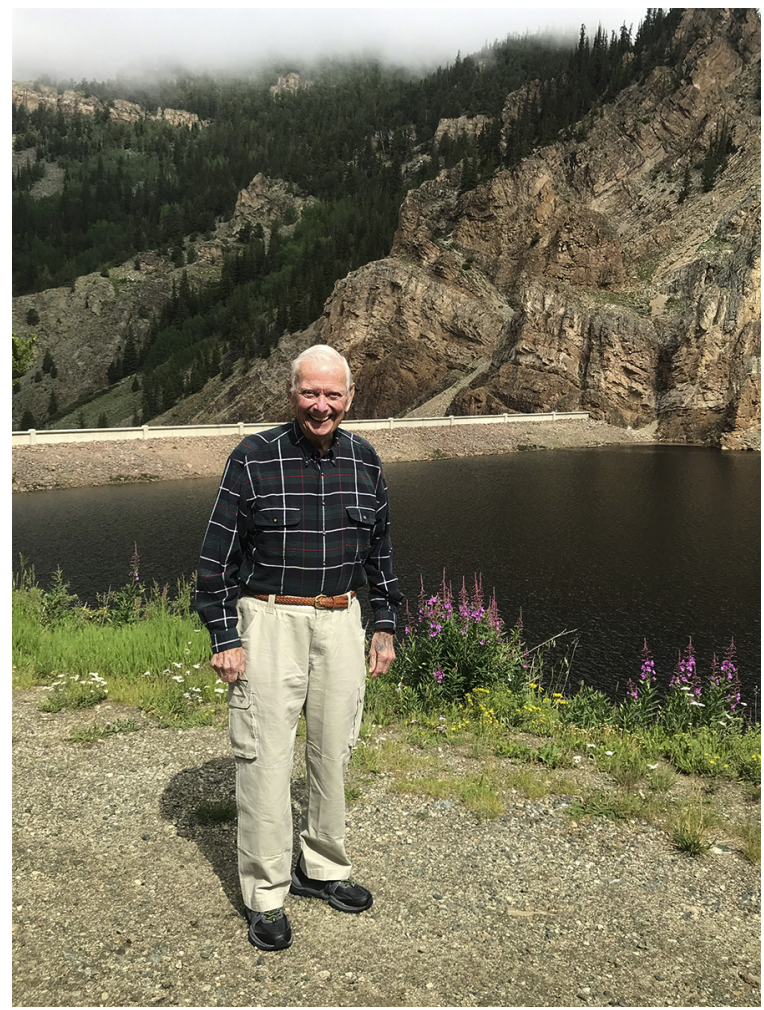

Near Crested Butte, Colorado (July 2019). Photo courtesy of Mary Lou Layton.

4 years; and planned a triptych of paintings memorializing wilderness medicine themes to be displayed at the annual meetings - all efforts to imbue the WMS with both social respect and meaningful purpose.

He was my mentor and my friend. My membership in the WMS has given me great privileges, among which it has introduced me to many heroes. Blair Erb ranks at the top of that list.

William W. Forgey, MD

Blair Erb was an early and constant supporter of the WMS, serving as its fourth president. In remembrances among the other past presidents, the description used repeatedly is "Southern gentleman." He was a lifelong son of the South, but the term "gentleman" is no longer in frequent use and warrants explanation. Blair was attentive, compassionate, and had a calm and thoughtful demeanor. He did not have any hint of prejudice or arrogance. Although he had a certain formality, as evidenced by the purchase (at his own expense) of a green sports coat for all the WMS presidents, he was not stiff or inflexible, and he had a good sense of humor. In the early days of the WMS, he added his experience with other medical societies and a vision of a society based on a 


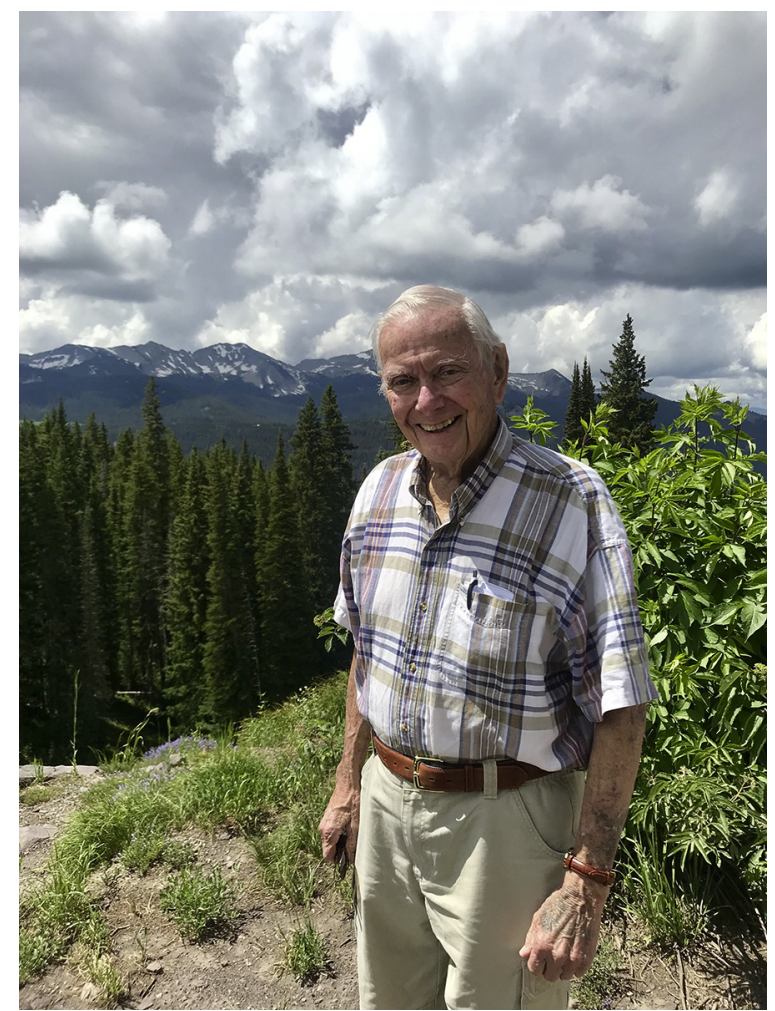

Near Crested Butte, Colorado (July 2019). Photo courtesy of Mary Lou Layton.

common passion as well as medical science. While president, he fully endorsed and developed the first World Congress on Wilderness Medicine in partnership with other organizations. Blair was able to add a historical perspective to wilderness medicine and provide depth with his specialty of cardiology and keen interest in exercise physiology and cardiac rehabilitation. For example, I learned from Blair that for the purpose of predicting cardiac risk for wilderness activities, participants could be divided into 5 categories, from demonstrated high performance to significant limitations from chronic illness, but the ones who were most concerning were those who were formerly athletic but now deconditioned with risk factors, because they overestimated their ability. Blair Erb's love of the outdoors and wild places as well as medicine was palpable. He imparted that to the WMS, and we will miss both his enthusiasm and his gentleman's demeanor.

Howard Backer, MD, MPH

As many have reminisced, Blair Erb was a Southern gentleman, but he was so much more. Although he was from Tennessee, he never tired of reciting a poem by Robert Service, "The Cremation of Sam McGee." Sam McGee was also from Tennessee, but the similarity may have ended there. Sam was always cold in the Yukon, a condition that only resolved when he died, presumably of hypothermia, on the day after Christmas on the Dawson Trail. Sam McGee was cremated, at his own last request, several days later. Blair often referred to Sam's cremation as a case of therapeutic excess.

As president of the WMS, Blair came to Alaska to speak at a wilderness medicine conference organized by Peter Hackett. Blair suggested that we start an Alaska chapter of the WMS. Peter and I started the chapter and had an initial meeting before we found out that chapters were not mentioned in the WMS bylaws. Also not mentioned in the bylaws was the fact that there was no way to amend the bylaws.

I came to Blair with the idea that the WMS should start a library of photographs. In those days, before PowerPoint, photographs for lectures were on slides, so I suggested a slide bank from which members of the WMS could obtain photographs that they might not have themselves for use in lectures. Blair thought for a moment and suggested instead that the WMS could develop educational slide sets, so that a speaker could give an entire prepared talk using the slide set. Although he hardly knew me, he appointed me to run the project. That was the start of the WMS educational presentations.

There was always more to Blair than met the eye. He was 1 of the 4 American members of the Austrian Society for Mountain and High Altitude Medicine (ÖGAHM). He may have joined partly to support his friend Franz Berghold, the president of the ÖGAHM. The other 3 members were Blair's 2 sons and me.

Blair was always a welcome presence at WMS meetings, usually accompanied by his wife, Sally. He encouraged younger members like me to contribute to the society. He was instrumental in making the WMS what it is today and he did it in a typically understated style. In his later years, he willingly took on an assignment to speak about elderly people in the wilderness at a WMS meeting. The first slide, he said, illustrated his own condition. He had seen it in the airport on his way to the meeting, a sign that said "Terminal." He found a way to stop by WMS meetings for many years, even after he was no longer active in the society. I will always remember Blair's genial and inspiring presence.

Ken Zafren, MD 